\title{
Globalization and Modernity: Revocation of Space and Time between Broadcaster - BPRS ERA FM UNJ to Edufren
}

\section{Dewi Soleha}

\section{Abstract}

This paper will examine globalization and modernity from the perspective of Anthony Giddens, where there are conditions indicated by the separation of time and space as well as the revocation of space and time, in which the globalization of the mark with the revocation time and space, like the relationship that exists between the broadcaster and Edufren (designation for listeners ERA FM). Revocation of time and space occur in conditions that do not localized through the relationship that exists through the frequency bands and social networks, such as Facebook and Twitter, thereby eventually giving birth to reflexivity individuals and institutions as well as risks in globalization. It is reflective of ERA FM listeners by describing his self-expression

Corresponding Author: Dewi Soleha; email: dd.dewi12@gmail.com

Received: 09 April 2017 Accepted: 17 May 2017 Published: 12 June 2017

Publishing services provided by Knowledge E

(c) Dewi Soleha. This article is distributed under the terms of the Creative Commons

Attribution License, which permits unrestricted use and redistribution provided that the original author and source are credited.

Selection and Peer-review under the responsibility of the ICoSaPS Conference Committee.

\section{G OPEN ACCESS} through a network of listeners social. Where is trying to be someone that is modern. Meanwhile, the reflective institutions as well as the revocation of space and time through the good or bad news are delivered by radio. Thus, motivating institutions to make better and prevent the risks of globalization. Thus, the individual or institution is doing discursive consciousness to defend themselves on the wave of globalization.

Keywords: Anthony Giddens, Community, Globalization, Juggernaut, Modernity, Radio

\section{Introduction}

This paper will discuss globalization and modernity from Anthony Giddens 'perspective. The authors tune the repeal of space and time between the broadcaster and Edufren (call for listeners ERA FM), where the two subjects underwent revocation conditions of space and time with each other through radio and social networking. When assessing the repeal of space and time between broadcaster and listener, the author uses the concept of globalization. Because this concept is the one used to describe the conditions where the boundaries between various subjects become blurred, these conditions are addressed directly distant relation that can penetrate time and space. So, there are people who can organize the relationship between space and time resulting in a condition called modernity. 
The condition of modernity is a sign of globalization. This situation is shown by the separation of time and space as well as the revocation of space and time. When broadcasters and Edufren (call for listeners ERA FM) in the no localized context, in addition to the conditions envisaged between the broadcaster and Edufren (call for listeners ERA FM), there are also conditions of the subject's action pattern, in the form of an attitude of dependence with other parties. Where there is a dependent position of Edufren (call for listeners ERA FM) with broadcasters, dependence is created because of the need for Edufren (call for listeners ERA FM) in which information and entertainment are provided by the broadcaster. The state is what allows the relationships between the various communities, allowing to occur in various parts of the world, as assumed by Giddens as follows "Globalization refers to the fact that we are all increasingly living one world, so that individuals, groups, and nations become interdependent" [4]. Essentially, the world will be merged into one. No more corners in this world are isolated because all of them have been linked to global communication networks; communication is through not only the boundaries of the region but also cultural and even diluting personal borders. So here we can view the process of globalization involving heterogeneous between different subjects. The process of globalization is the "intensification of worldwide social relations linking distant regions in the way that local happenings are shaped by events occurring many miles away and vice versa" thereby changing all aspects of our daily life. So, the problem formulated in this paper is how is the process of globalization and modernity by Giddens? How is the relations between the broadcaster and Edufren (call for listeners ERA FM) in conditions of Giddens' globalization and modernity? What kind of risks arise from modernity and globalization?

\section{Overview of BPRS ERA FM UNJ}

BPRS ERA FM UNJ is a campus community radio at UNJ. Initially this community was established by students from the Department of Electricity and the Faculty of Engineering. They are students who are aware of the lack of information on campus news and events. In addition, they really need mass media that are cheap, fast and easily accessible. Therefore, a radio community was established. Before that SRB ERA organizes UNJ FM broadcasting frequency. SRB ERA organizes UNJ FM radio broadcasts via a cable mounted on the corners of the campus like the cafeteria and student hangout. This community was established in 1999. At the beginning of this community radio formation, the conditions shift and they are still nomadic.

In 2001, this community was still legal, and in the BPRS ERA FM organizes UNJ been broadcast through line frequency. But in the following year this community to block by the authorities because they do not have a broadcast license and to stop broadcast 
out of the campus community and this broadcast is heard in the community outside the campus. At the time of blockage, this community is regarded as a disseminator of the Left and the country and as rebels. So, until 2004, they undergo a process legalized from the campus and KPI (legal Indonesia Broadcasting Commission). Finally, the campus radio community was legalized in 2004 by decree of the Rector. But when in 2007 the SRB ERA FM UNJ firmly reprimanded by the IEC with the threat broadcasting prohibited. Strikes by KPI for Announcer community radio have been out of bounds rules community radio is a maximum of $5 \mathrm{~km}$. When it turned out to be SRB ERA FM UNJ it experiences technical interference which frequency leakage. It is because the leak has been obsolescence of the transmitter anyway transmitter is assembled with second-hand goods and simple tools.

\section{Modernity: Juggernaut and Edufren}

Giddens said that modernity of today's society is "Juggernaut" so there are certain limits that cannot be controlled [2]. That is a condition characterized by a state of society that has been able to organizethe relationship between space and time resulting in the revocation of space and time. Then, the time can be controlled so that the time can transcend physical space. So the limit - the limit can no longer be controlled. This is called globalization in Giddens' view. Abstract people are no longer separated between space and time. Then, the boundaries between communities become blurred. So there was the process of modernity which eventually gave birth to globalization. The conditions of globalization called by Giddens as modernity juggernauts are as follows:

Machines that continue running with terrible force that collectively as human beings we can push it to the limit - a certain extent but it is also very possible to be separated from our control and slammed into him, crushing them against the juggernauts. Although sometimes they follow a straight groove, there are times when they change the course direction unexpectedly. They ride altogether unpleasant and disappointingly; often times, happy and full of hope. But controlling groove or track his journey, in turn, we will not feel ever completely safe because the path is full of risks bringing heavy Risks [2].

Juggernaut as aforementioned is a form of dynamic modernity. Juggernaut itself describes something moving in unison, through time and space beyond the physical. Giddens assumes that time and space is the central factor to address globalization [3]. Because all of the actions take place only in time and space time and space are coordinated in terms of social practice distinguishing modern society from the traditional one. Because the pre-globalization people of all social practices carried out at a time and place that is localized, it is different in the current era of globalization community social 
practice they can be done in time and space that is not localized. Then, there was the time of the revocation process space on a global scale. This is where the address that people can organize between space and time, when they establish social relations.

From the condition existing between the broadcaster and the audience, it can be seen that there UNJ community infrastructure experiences globalization, which eventually leading to the change. That is, the relation changes at first if you want to say something or information should be in the context of localized, but the relation exists only between broadcasters and listeners in relation to the not localized conditions. The interactive capabilities of Information and Communication Technologies (ICTs) which overcomes time and space borders facilitate the flow of information directly and there is listeners' feedback and their level of participation. In this relation, there was a very instrumental role of the internet, through social networks such as Facebook and twitter. Then the listeners not only hear but also can provide feedback to the broadcasters. Not only generated by the internet technology, both broadcasters and listeners can learn through existing information either directly to the professional person, such as in broadcasts bring in an expert to participate in joint broadcast announcer.

\section{Self-reflexivity Edufen and Institutions in Globalization on Radio}

We have discussed the uprooting of space and time is a symptom of modernity that gave birth to globalization. In this discussion section, we will discuss about self (self) and institution reflexivity when there are symptoms of globalization. Reflexivity is a regular monitoring of yourself and your behavior in order to decide who you are and how you live.

In Giddens' view, living in the era of globalization (of late modernity) is meant that we are not able to accommodate changes and uncertainty with re-creating our lives lifetime - then an activity called reflexivity takes place. Reflexivity is a situation where there is a reaction and stimulus when modernity comes then unconsciously we will respond to conditions or product of modernity, eventually leading to globalization, the conditions to respond to the products of globalization. Then we catch the core symptoms impossibility because there is no core to what running helter-skelter. So here we are required to establish our discursive consciousness, and consciousness of our practical, to search the core of the product of globalization. Although in the end we are not able to capture the essence, we try to reduce the risk of a global product which we predicted or imagined. Not only experiencing self-reflexivity in globalization; but it also turns out to be the institution's conduct reflexivity practice in defending itself from globalization. When this reflectivity arises because agent institutions try to do discursive consciousness in to re-globalization, they can defend themselves. One 


\begin{tabular}{|c|c|c|c|}
\hline Institutions & Risk and Problem & $\begin{array}{l}\text { Movement } \\
\text { (reflection form) }\end{array}$ & Goals (reflection) \\
\hline Capitalism & $\begin{array}{l}\text { Economic } \\
\text { polarization and the } \\
\text { commodification of } \\
\text { life }\end{array}$ & $\begin{array}{l}\text { The labor } \\
\text { movement }\end{array}$ & $\begin{array}{l}\text { Rights - economic } \\
\text { rights (material) }\end{array}$ \\
\hline Industrialism & $\begin{array}{l}\text { Environmental } \\
\text { damage }\end{array}$ & $\begin{array}{l}\text { The environmental } \\
\text { movement }\end{array}$ & $\begin{array}{l}\text { Ethical and moral } \\
\text { imperative use of } \\
\text { technology }\end{array}$ \\
\hline \multirow{2}{*}{$\begin{array}{l}\text { Spy as state } \\
\text { system - the } \\
\text { nation } \\
\text { Military }\end{array}$} & $\begin{array}{l}\text { The rejection of } \\
\text { democracy and } \\
\text { rights }\end{array}$ & $\begin{array}{l}\text { Democracy } \\
\text { movement and } \\
\text { rights }\end{array}$ & $\begin{array}{l}\text { Rights - political } \\
\text { rights }\end{array}$ \\
\hline & $\begin{array}{l}\text { War and repression } \\
\text { by Violence }\end{array}$ & $\begin{array}{l}\text { Movement } \\
\text { peacekeeping }\end{array}$ & $\begin{array}{l}\text { Rights - civil rights } \\
\text { dealing with the } \\
\text { military police. }\end{array}$ \\
\hline
\end{tabular}

TABLE 1: Reflexivity into globalization.

of the reasons for their lack of action reflective of mass media like radio is always preaching these institutions, both good and bad news. Thus, this institution continues to develop itself into the better one. From this condition, it can be seen the repeal of space and time. So how do broadcast media such as radio motivate the institutions to try to capture the essence of the world runway symptoms by addressing the response of risk prediction? Such the institution supports the following conditions of modernity: capitalism, the state - nation, military and industrialism. As in the Table 1.

The table above is a social practice that is assessed and recovered continuouslyagain, according to new information that in turn changes to globalization, through certain constitutive practices. Due to the reflexivity - the institutional organization living together will match mostly the conditions of globalization. It is the reflection because there is a risk - a risk that will be brought on by globalization. For example, as manifested in the above table, the occurrence of industrialization in globalization results in the prediction and shadows on the risks that will occur such as environment damage, from the shadows or risk prediction of industrialism, leading tithe forms of reflexivity that is the way the environmental movement as go green. Such movement is carried out in order to maintain the natural environment and empower them wisely, which is a form of ethics and moral interpretive targeted use of technology. It is addressed in such a way that the technology used nature-friendly industry, with the aim that we are living in an era of globalization to remain to be safe from natural hazards. From the explanation concerning reflexivity institutions in globalization above, it can be seen that all of them have been discussed in a broadcast on ERA FM. It suggests that ERA FM can also be dragged into modernity conditions of globalization, because what is described above is part of a unified theme to hold ERA FM broadcast. 


\section{The Concept of the Globalization Risks Edufren Accord- ing to Giddens}

In the above discussion, we discussed the reflexivity of individuals and institutions in facing globalization. Reflexivity is inaction in the face of globalization, namely to prevent the risks that will occur as a result of globalization. Risk is a culture of globalization and the risk to fundamentalist society globalization. Because fundamentalist is the biological child of globalization, when we are in these conditions there is nothing to be considered. Because fundamentalist arises from the forms of risk generated by globalization, this is called the global as well and local (upward). This is because globalization is increasingly decentralized with any other countries or nations, playing a major role in globalization. Besides, globalization can weaken the local culture and serve to awaken a way of reflexivity. This is the forces of globalization that are used to achieve the fundamental objectives. Fundamentally, the shape of dual system includes religious, ethnic, and nationalist politics. Giddens 'fundamentalist reveals that this is a form of risk from globalization, because of the fundamental as the problems, leading to the possibility of violence, and he becomes the enemy of values cosmopolitan.

Giddens distinguishes two types of riskin globalization: natural and artificial risks. Natural risk is the risk that the natural forms come from the outside, because of the strong tradition or nature. Risks that occur naturally in ERA FM is like weather disturbances that could break and damage the of line frequency during heavy rain. Meanwhile, artificial risk is the risk created by the huge impact the development of human knowledge has on the world. Risks generating artificial forms of reflexivity have been discussed earlier. Increased risk in the globalization of science becomes the protector of global contamination of humans and nature. Here we can see that the role of knowledge as a shaper of a risk but he at the same time as protection or means to neutralize the risk. Considering the concept above, we are required to have discursive consciousness in the face of risk. This discursive consciousness is a consciousness that is constructed by ERA FM SRB UNJ to the audience. It is seen from the themes and content were removed ERA FM broadcasts. News and information presented by ERA FM makes edufren thinking and critical of something common sense in society. Discursive consciousness plays the roles, there will be a choice and the choice is exactly in make sure there is a risk in it as expressed by Giddens is as follows: "Either way you choose, we are always dealing with the Management of risk [3]. With the spread of the risk created, Giddens develops structuring approach in order to analyze the relationships between structure and agency dialectic in globalization, to analyze risks and uncertainties that ultimately is a reflexive action of the predicted or imagined risks [2]. 


\section{Summary}

Globalization and modernity in Anthony Giddens' view is the globalization characterized with the time and space revocation, where there is a condition that is not localized between broadcaster and Edufren. It is the relationship existing between the broadcaster and Edufren. Revocation of time and space occur in conditions that are not localized through the relationship existing through the frequency of bands and social networks, such as Facebook and Twitter. From these relationships created the listeners' reflexivity in their expression. Edufren reflection occurs when it started its relationship with the broadcaster in the way it was involved in broadcasting indirectly, through writing on wall or dimension to participate in the broadcast held in which there is a reflection of an of listeners'self expression. Reflexivity is not only by individuals but also by institutions in which this reflexivity arises because agent institutions try to do discursive consciousness in overcoming globalization so that they can defend themselves. One of the reasons for the lack of reflective action of mass media such as radio is preaching institution, both good and bad news. Thus, this institution continues to develop itself into the better one. From this condition, it can be seen the repeal of space and time. So, what broadcast media such as radio reflection motivate itself to be the better one, i.e. the reflective action aiming to enable the self and institution to survive in globalization facing the shadows and prediction of the risk incurred, which is the effect of globalization. In this way, they act in the form of discursive consciousness. Thus, they can interpret the risks generated by globalization. The risk inherent to globalization in Giddens' concept is divided into two: natural and artificial risks.

\section{References}

[1] Calhoun, Craig et al. (2012), Classical Sociological Theory. Third edition. West Sussex: Wiley Blackwell.

[2] George, Ritzer. (2009), Teori Sosiologi: Edisi Baru. Yogyakarta: Kreasi Wacana.

[3] Giddens, Anthony. (2006), Sociology Fifth Edition. Cambridge: Polity Perss.

[4] Giddens, Anthony. (2000), Runway World: How the Globalization of Reshaping our life. New Work: Routledge.

[5] G. Meštrović, Stjepan. (1998) Anthony Gidden: The Last Modernist. London: Routledge. Joseph, Jonathan. (2005). Social Theory a Reader, ed. Edinburgh: Edinburgh University Press.

[6] Jones, Pip. (2010), Pengantar Teori - TeoriSosial; dari Funngsionalisme Hingga Postmodenisme Jakarta: Obor.

[7] Priyono, Herry. (2002), Anthony Giddens: Suatu Pengantar. Jakarta: Gramedia. 
[8] Syaifudin. (2010), Meniti Aktifitas Perfileman di ORMAWA. Jejaring Sosial Facebook dalam Komunitas Sinematrafitelevisi UNJ. Jurnal Scripta Societa, Titian komunitasmadani: vol 4, Jakarta: lab Sosiologi UNJ.

[9] Nicholas C. Georgantzas, ect. Giddens' globalization: Exploring dynamic implications. Fordham University, GBA, 113 West 6oth Street, Suite 617-D, New York, NY 10023-7484, USA, http://www.setav.org/ups/dosya/15100.pdf, on accessed on November 18, 2012.

[10] puslit.petra.ac.id/journals/pdf.php? PublishedID=IK009030105, accessed on 18 November 2012. 